\title{
Rituximab: uma alternativa terapêutica para o tratamento da trombocitopenia imunológica
}

Rituximab é uma nova medicação aprovada para o tratamento do linfoma do tipo B. Trata-se de um anticorpo monoclonal contra o antígeno CD20 (pan B). Este antígeno está presente nas células pré $\mathrm{B}$ e persiste através de todos os estágios de diferenciação de linfócitos $\mathrm{B}$, presente nos linfócitos maduros e neoplasias de células $\mathrm{B}^{(1)}$.

O seu desenvolvimento abriu a possibilidade de que talvez pudesse também ser útil no tratamento de outras enfermidades autoimunes refratárias ${ }^{(2)}$. Relatos isolados do uso do Rituximab em autoimunidade B mediada parece levantar a possibilidade de que sua indicação venha a ser mais ampla do que exclusivamente no tratamento de linfomas. No presente trabalho descrevemos dois casos de púrpura trombocitopênica idiopática de natureza autoimune onde o uso do Rituximab levou a uma remissão prolongada do quadro clínico.

O primeiro caso foi de uma paciente de 42 anos com quadro de dores articulares e trombocitopenia, do sexo feminino, cor branca, $80 \mathrm{~kg}$, profissional liberal. História pregressa significativa quando, três anos atrás, apresentou sangramento espontâneo associado a plaquetopenia (19x10 plaquetas/l). Iniciou tratamento com corticóide (60 mg/ dia) sem resposta clínica. Posteriormente, fez uso de gamaglobulina endovenosa com discreta melhora (contagem de plaquetas 39x10/1). Nessa ocasião, foram detectados a presença de dores articulares e o aparecimento de anticorpos antinucleares (FAN 1/640, anti-DNA por Chritidia luciliae positivo). O tratamento com Rituximab (375 mg/ $\mathrm{m}^{2}$ ) foi instituído (quatro doses seguidas), com aumento gradual das plaquetas $(126 \times 10 / 1)$. Tratamento de manutenção com $5 \mathrm{mg}$ de prednisona e antiinflamatório nãohormonal. Seis meses após o tratamento a paciente mantém-se em remissão.

O segundo caso foi o de C.M.A., 18 anos, $90 \mathrm{~kg}$, estudante, cor branca, PTI diagnosticada em 1997. Utilizou meticorten com respostas transitórias. Há cerca de dois anos fez IgG EV e esplenectomia, permanecendo assintomática até junho de 2002, quando apresentou petéquias, equimoses e sangramento bucal. Foi submetida a IgG EV e quatro pulsos de enduxan com recidiva. Tentando ciclosporina, não houve resposta. Em novembro de 2002 foi introduzido Rituximab $375 \mathrm{mg} / \mathrm{m}^{2} / \mathrm{semana}$ por 4 semanas. Desde então está em remissão completa.

Pacientes portadores de doenças auto-imunes mediadas por anticorpos, em um número importante de casos, respondem ao tratamento por corticóides ou agentes citotóxicos, ou ambos. Uma má resposta clínica a esses agentes geralmente está associada a um prognóstico reservado. $\mathrm{O}$ rituximab tem provocado uma redução acentuada de linfócitos B (antígeno CD20) por um período de 6 a 9 meses, tornando-se uma boa opção terapêutica para algumas doenças auto-imunes. Trata-se de uma medicação com um número relativamente pequeno de efeitos colaterais, em geral em virtude de reações alérgicas.

Rituximab tem sido relatado como de utilidade em outras doenças auto-imunes ${ }^{(3)}$. Tanto no caso dos nossos pacientes como nos pacientes da literatura, acredita-se que o mecanismo de ação esteja interferindo na sobrevivência de linfócitos B, produzindo auto-anticorpos, apesar de os níveis séricos de imunoglobulinas não parecerem sofrer flutuações importantes.

No presente trabalho, relatamos o efeito benéfico do Rituximab em dois pacientes com púrpura trombocitopênica idiopática refratária ao tratamento convencional e com remissão prolongada após as aplicações da medicação. O seu mecanismo de ação parece estar ligado à eliminação de células produtoras de auto-anticorpos. Resultados semelhantes foram relatados no decorrer dos últimos dois anos por outros investigadores ${ }^{(4,5,6)}$. Em suma, o Rituximab parece ser uma alternativa viável para o tratamento de trombocitopenia de natureza imune refratária ao tratamento convencional ${ }^{(7)}$.

\author{
MORTON SCHEINBERG \\ Nelson Hamer Schlack \\ José Mauro Kutner \\ Andreza Alice Feitosa Ribeiro \\ Hospital Israelita Albert Einstein
}




\section{REFERÊNCIAS}

1. Treon SP, Anderson KC: The use of Rituximab in the treatment of malignant and non malignant plasma cell disorders. Semin Oncol 12: 79-85, 2000.

2. Arzoo K, Sadeghi S, Liebman HÁ: Treatment of refractory antibody mediated autoimmune disorders with an anti CD20 monoclonal antibody (Rituximab). Ann Rheum Dis 61: 922-4, 2000.

3. Edwards JC, Cambridge G: Sustained improvement in rheumatoid arthritis following a protocol designed to deplete B lymphocytes. Rheumatology 40: 205-11, 2001.
4. Stasi R, Pagana A, Stipa E, Amadori S: Rituximab chimeric anti CD20 monoclonal antibody treatment for adults with chronic idiopathic thrombocytopenic púrpura. Blood 98: 952-7, 2001.

5. Patel K, Berman J, Farber A, Caro J: Refractory autoimmune thrombocytopenic púrpura treatment with Rituximab. Am J Haematol 67: 952-7, 2001.

6. Arzoo K, Sadeghi S, Liebman HÁ: Treatment of refractory antibody mediated autoimmune disorders with an antiCD20 monoclonal antibody (Rituximab). Ann Rheum Dis 61: 922-4, 2002.

7. Looney RJ: Treating human autoimmune disease by depleting $B$ cells. Ann Rheum Dis 61: 863-6, 2002.

\section{Necrose tecidual após injeção de diclofenaco de sódio}

Em agosto de 2001, no exercício da função de Conselheiro do Conselho Regional de Medicina do Estado de São Paulo (Cremesp), fomos designados para realizar sindicância e parecer em relação à denúncia de um caso de lesão cutânea e muscular causada pelo uso de diclofenaco de sódio intramuscular.

Tratava-se de uma paciente de 37 anos de idade, cor branca, submetida ao procedimento de videohisteroscopia para retirada de pólipo endometrial. Ainda na sala de recuperação pós-anestésica, foi medicada com uma ampola (75 mg) de diclofenaco de sódio intramuscular aplicada corretamente no quadrante superior externo da nádega direita, em razão da queixa de cefaléia. Em poucas horas desenvolveu reação local caracterizada por placa eritematosa, dor em queimação, evoluindo com intenso processo inflamatório. Após alguns dias, segui-se de necrose tecidual atingindo pele, tecido celular subcutâneo e músculo. Não apresentou na evolução sinais de infecção, sendo tratada com cuidados locais e desbridamentos cirúrgicos, resultando, após aproximadamente 60 dias, em lesão cicatricial extensa e inelástica.

Em levantamento feito nos arquivos do Cremesp, encontramos quatro outros casos bastante semelhantes no período de 1995 a 2002. As indicações para o uso de diclofenaco de sódio injetável nesses pacientes foram: cólica renal, trauma em cotovelo direito, lombalgia aguda e trauma em punho esquerdo. Em dois desses casos, a medicação foi feita no músculo deltóide, sendo que um dos pacientes tinha 13 anos de idade. Em três casos foram lavrados Boletim de Ocorrência (B.O.) com conseqüente inquérito policial. Todas as cinco sindicâncias foram arquivadas no Cremesp por inocorrências de infrações técnicas ou éticas por parte dos médicos envolvidos.
Em nosso meio, Golcman et al. ${ }^{(1)}$ e Giovannetti et al. ${ }^{(2)}$ relataram, respectivamente, quatro e sete pacientes com quadros de necrose tecidual após injeção intramuscular de diclofenaco de sódio com características muito semelhantes aos casos levantados por nós no Cremesp. Há na literatura internacional raras citações dessa ocorrência ${ }^{(3,4)}$. A fenilbutazona é o antiinflamatório mais freqüentemente relacionado à necrose tecidual ${ }^{(5)}$, com manifestações semelhantes à encontrada em nosso meio.

O diclofenaco de sódio é um antiinflamatório não-hormonal derivado do ácido fenilacético que apresenta potente ação analgésica, antiinflamatória e antipirética. Seu uso pode ser feito via oral, retal ou intramuscular. Em virtude de suas características, esse medicamento tem sido largamente utilizado nas afecções reumáticas inflamatórias e/ ou degenerativas, assim como nas inflamações pós-traumáticas, analgesia pós-cirúrgica e processos dolorosos em geral. A tolerabilidade desse fármaco é considerada boa, sendo raros os casos de efeitos colaterais graves. A apresentação comercial para a aplicação intramuscular é ampolas de $3 \mathrm{ml}$ contendo $75 \mathrm{mg}$ do fármaco.

Golcman et al. ${ }^{(1)}$ enumeram os cuidados para a prevenção dessa ocorrência:

1. As aplicações só devem ser feitas por pessoas que conheçam as normas fundamentais que norteiam essa técnica.

2. Escolha adequada do local da aplicação, dando-se preferência à região glútea, que tem maior massa muscular e é menos passível de vasopunção que o músculo deltóide, sob cuja borda posterior passam os vasos circunflexos e suas principais tributárias. Esses vasos são os mais atingidos nos casos de acidente. 